\title{
Innovation after the French Revolution, or, Innovation Transformed: From Word to Concept $^{1}$
}

Benoît Godin, l'Institut national de la recherche scientifique

\begin{abstract}
For centuries, innovation has been a pejorative concept, and there has been no study of what innovation is. How, when and why did innovation become an object of theory - and dreams? This paper is about that key moment in the history of innovation as a concept. Innovation got rehabilitated at the moment when it came to be defined as utility or progress. This occurred between c. 1750 and c.1850: innovation becomes instrumental to political and social - and later material or economic - goals.
\end{abstract}

Keywords: innovation, concept, religion, politics, intellectual history

\section{Introduction}

L'esprit d'innovation ... est le plus beau don que la nature ait fait aux hommes. Sans lui, l'espèce humaine croupiroit (Jacques-Pierre Brissot de Warville, De la vérité, 1782).

On ne doit jamais craindre d'innover, quand le bien public est le résultat de l'innovation ... Chaque siècle ayant d'autres moeurs, \& des usages nouveaux, chaque siècle doit avoir de nouvelles loix (Comte de $\mathrm{M}^{* * *}$, L'innovation utile, ou la nécessité de détruire les Parlements: Plan proposé au Roi, 1789).

"Not one in a hundred amongst us participates in the 'triumph' of the Revolution society .... Thanks to our sullen resistance to innovation, thanks to the cold sluggishness of our national character, we still bear the stamp of our forefathers. We have not (as I conceive) lost the generosity and dignity of think- 
ing of the fourteenth century; nor as yet have we subtilized [sic] ourselves into savages. We are not the converts of Rousseau; we are not the disciples of Voltaire; Helvetius has made no progress among us". So spoke Edmund Burke in Reflections on the Revolution in France (Burke, 1790: 64). To Burke, innovation is revolution - and revolution is innovation.

Burke (1729-1797), an Irish statesman and political philosopher, member (Whig) of the English House of Commons and founder of the political review Annual Register, offers two arguments against innovation. First, custom or "inheritance derived to us from our forefathers" is "the result of profound reflection; or rather the happy effect of following nature". In contrast, "A spirit of innovation is generally the result of a selfish temper and confined views" (Burke, 1790: 31).

Burke's second argument is a preference for the middle ground - which amounts to what he calls reform. "As in most questions of state, there is a middle. There is something else than the mere alternative of absolute destruction, or unreformed existence" (Burke, 1790: 158). According to Burke (A Letter to Noble Lord, 1796; in Ritchie, 1991: 290):

There is a manifest marked distinction, which ill men, with ill designs, or weak men incapable of any design, will constantly be confounding, that is, a marked distinction between Change and Reformation. The former alters the substance of the objects themselves ... Reform is, not a change in the substance, or in the primary modification of the object, but the direct application of a remedy ... To innovate is not to reform.

Burke held similar views throughout his life. Whether in his speeches to Parliament or his diverse correspondence, Burke cried out against "The greatest of all evil: a blind and furious spirit of innovation, under the name of reform" (Letter to William Elliot, 1795; in Ritchie, 1991: 271).

Such thoughts may seem strange to many readers. Today, we entertain a totally different representation of innovation. Innovation is essentially a good and positive thing. How, when and why did innovation become positive and become a fashion? For centuries, innovation was a contested concept, and there was no study or theory of what innovation is (Godin, Forthcoming-A). Such is the representation of innovation in pre-revolutionary France. This representation rests on a word of ordinary language and a word of opprobrium - innovation. The Seventeenth and Eighteenth centuries are well known for their distrust of language and Ars rhetorica (Skinner, 2002). Language is subject to much abuse, according to many, ${ }^{2}$ above all to the philosophers who in reply articulate projects for a universal language (Barny, 1978; Ricken, 1982; Slaughter, 1982). Such is the case with innovation. Everyone uses the concept but everyone disagrees on what innovation is. 
Innovation developed a positive connotation only at the moment when it came to be defined as progress and utility. This change in the meaning of innovation was not a response to (contradictions in) disputes, as has been the case for various political concepts (Ball and Pocock, 1988). To be sure, innovation is an eminently political and contested concept, as will become clear to the reader in the following pages. Yet it does not figure in the vocabulary of statesmen and political theorists of the seventeenth and eighteenth centuries, except as a 'non-concept': when talked of, it is talked of negatively. Innovation became an honourable concept in response to a new context. This paper is about this key moment in the history of innovation. After centuries of experience with and talk of innovation in negative terms, innovation turned positive and became an object of thoughts and dreams. This occurred after 1789: innovation became instrumental to social and political - and later material or economic - goals.

In the past few years, I have dealt at length with the pejorative representation of innovation, particularly in England. Innovation was forbidden by law in both religious and government matters. The concept started being used widely after the Reformation and increasingly so in the seventeenth century against any deviant, whether a puritan or a republican. This representation was shared in every Western country. The present paper concentrates on France although not exclusively -, and on the emergence of a new representation of innovation. The first part traces the representation of innovation in the century before the French Revolution. It shows that innovation was a negative concept used for accusatory purposes. "The purpose of all opprobrious language is, not to describe, but to hurt", suggests Clive Staples Lewis in Studies in Words. "We call the enemy not what we think he is but what we think he would least like to be called" (Lewis, 1960: 122). The second part documents the rehabilitation of innovation, a rehabilitation that occurred between c. 1750 and c.1850, that period of history Reinhart Koselleck designates as Sattelzeit, when many words changed meanings due to a "shift in the conception of time and a reorientation towards the future".

\section{On Method}

For the student of innovation, there exist very few titles entirely devoted to innovation and no theoretical writings on innovation before the Twentieth century. To some extent, the problem is not dissimilar to that of a student of antiquity. In his Idea of Progress in Classical Antiquity, Ludwig Edelstein mentions that no detailed discussion on 'progress' remains from classical antiquity, except fragments and brief sentences. Second, the evidence is widely dispersed 
(Edelstein, 1967). Nevertheless, Edelstein could produce evidence of 'progressivism' in antiquity from a non-negligible group "representative of a movement". ${ }^{3}$ The case is similar for innovation. For most of the period studied in the present paper, occurrences of the word innovation exist by the thousands. Every writer, from the anonymous to the most famous, makes use of innovation. However, there is no in-depth study. As this paper suggests, most of the time the word is used as a linguistic weapon or ideological arsenal for or against novelty.

A second factor complicates the analysis. Like Edelstein's source material, the occurrences of the word innovation are scattered. The usage is frequent but dissipated. One has to study politics, religion, history, law, science, arts, economics and other disciplines to properly appreciate the extent and diversity of uses, above all in pamphlets. Yet taken together, the documents suggest what the representation of innovation is to those at that time. As Keith Baker suggests in his study of pre-revolutionary writings in France:

\footnotetext{
"None of these (...) documents can properly be regarded as a classic work of political theory, as we tend to define that genre, though at many points they may bear the imprint of such works. Taken together, however, they clearly suggest the problems which French political thinkers faced on the accession of Louis XIV, the range of language in which such thinkers attempted to resolve those problems, and the tensions that this language often displayed" (Baker, 1990: 113).
}

The challenge to the student of innovation then, is the selection of source material. Since there is a limited amount of in-depth discussion on innovation before the Twentieth century, one has to study a voluminous number of texts in order to get a sense of what innovation is. Over the last years, I have collected hundreds of documents on innovation, from c. 1500 to 2000, from the anonymous writers to the most famous ones, trying to make sense of the uses of the concept. Given the voluminous source material, two options are available. First, one may (must) study those documents that use innovation only occasionally or casually (isolated occurrences). Studying isolated occurrences allows one to understand the broader context in which the word is used. Another option is to confine oneself to titles on innovation specifically. I have identified over 500 documents that contain titles with innovation in it, from the Renaissance to the late Nineteenth century. Of such titles, controversies (a title followed by replies and counter-replies) are the ideal sources since they allow one to understand the diverse purposes of use of the concept. In this paper, I have used both types of documents here: texts with a few or isolated occurrences of the word, and texts with titles on innovation. 


\section{Innovation before the French Revolution}

For centuries, few people talked of innovation in a positive way. To be sure, innovation was experienced everywhere, but as a concept it had a pejorative connotation. Innovation is political, and was understood as deviance, either in religion (heresy) or politics (revolution), the two being interwoven for centuries. Innovation is "introducing change to the established order". The political connotation of innovation needs to be stressed here because the literature on political thought has not included the concept among political ideas. ${ }^{4}$ The literature focuses rather on sovereignty, liberty, virtue, democracy, the republic, the constitution, the state and revolution. Yet innovation is a political concept too, first of all in the sense that it was regulated by Kings for centuries, forbidden by law and punished. ${ }^{5}$ Advice books and treatises for Princes and courtiers support this understanding, and include instructions not to innovate. Books of manners and sermons urge people not to meddle with innovation, and bishops visit parishes to make sure that the instruction is followed. From the Renaissance onward, innovation is also a linguistic weapon used by political writers and pamphleteers against their enemies.

Burke uses the concept in the same sense. England has a long history of such uses. Two controversies of the seventeenth century crystallized the meaning of innovation in that country for centuries to come. One controversy concerned the 'purity' of Protestantism and the "innovating" King Charles I and his protégé Archbishop William Laud (Godin, 2010). The other was that of the Republicans as political innovators against the monarchy (Godin, 2012-13). In both cases, the "innovators", as they were called, or rather accused of being, lost their case. Charles and Laud were beheaded, and the Republican experiment ended with the restoration of the monarchy.

France is no different. In both religion and politics, innovation is a bad word, statistically speaking. ${ }^{6}$ Jacques-Bénigne Bossuet (1627-1704), French bishop, theologian and polemicist, was an ardent opponent of innovation, particularly the Reformation.: "Evitez lez nouveautez dans vos discours, car les choses n'en demeureront pas là; une nouveauté en produit une autre, \& on s'égare sans fin quand on a une fois commencé à s'égarer" Bossuet, 1688: préface). In every work and in many letters, Bossuet does not refrain from using the word innovation against the Protestants. Histoire des variations des Églises protestantes (1688) is a work against the Protestants' "spirit of innovation". To Bossuet, a society needs rules, and rules require an authorized interpreter. But the Protestants vary on fundamental points. They commit the "crime d'innovation".

In his Lettre pastorale (1698) written in opposition to the bishop of Chartres, whom he accused of "variations", Bossuet denies any innovation in the Catholic Church. These are only "accusations en l'air", claimed Bossuet (Opuscules, 
1751: 226). The "novateurs" are rather the Protestants (Opuscules, 1751: 225):

Jamais on ne montrera dans l'Église Catholique aucun changement que dans des choses de cérémonie $\&$ de discipline, qui dès les premiers siècles ont été tenues pour indifférentes. Pour ces changements insensibles qu'on nous accuse d'avoir introduits dans la doctrine; dès qu'on les appelle insensibles, c'en est assez pour vous convaincre qu'il n'y en a point de marqués, \& qu'on ne peut nous montrer d'innovation par aucun fait positif. Mais ce qu'on ne peut nous montrer, nous le montrons à tous ceux qui nous ont quittés: en quelque partie du monde Chrétien qu'il y ait eû de l'interruption dans la doctrine ancienne, elle est connue: la date de l'innovation \& de la séparation n'est ignorée de personne.

Bossuet forgets here the controversy on innovation in England (1637-41), when the bishops accused the Protestant church of innovations in discipline and doctrine, precisely because it was believed that the innovations brought this church toward the superstitious and "innovating" Catholic Church. He forgets also that what he calls "indifférentes" innovations (insensible changes or small innovations) are nevertheless innovations to many divines, because of their symbolic value.

In the 1670s, Bossuet worked on a 'book of advice' to the Prince, namely the Dauphin (Louis XIV's son), for whose philosophical, political and religious education he was responsible. At the time, many books of advice included instructions on innovation. So does Bossuet's Politique tirées des propres paroles de l'Écriture sainte. The work is composed of ten books, each divided into articles and each article into propositions. The work was published posthumously in 1709. Politique offers rules and duties in light of the Bible. It is God who speaks in this book, not Bossuet. Book Seven is concerned with the duties of a Prince. It starts with religion and includes the following propositions (Lachat, 1864: 32-39):

La vraie religion a pour marque manifeste son antiquité.

Toutes les fausses religions ont pour marque manifeste leur innovation.

Cette marque d'innovation est ineffaçable.

Such a representation of innovation in religion is far from unique. In 1746, Denis Diderot (1713-1784), philosopher and co-editor of the Encyclopédie (1751), published his first work - anonymously. The Pensée philosophiques is a pamphlet on religion, condemned to be burned by Parliament as soon as it appeared. Composed of a series of letters, the thirteenth starts as follows: "Toute innovation est à craindre dans un Gouvernement ... Le Christianisme même ne s'est pas affermi sans causer quelques troubles. Les premiers enfans de l'Eglise sont sortis plus d'une fois de la modération $\&$ de la patience qui leur étoient prescrites". To Diderot, citing the Emperor Julian, the Christians 
"n'épargnent aucun moyen, ne laissent échapper aucune occasion d'exciter des révoltes". Yet, "C'est par la raison \& non par la violence qu'il faut ramener les hommes à la vérité".

Many responses, most of them published anonymously (1747; 1751a; $1751 \mathrm{~b} ; 1761)$, followed the publication of the pamphlet. The type of reply is shared by most of the writers involved in the controversy. Innovation per se is not a bad thing; everything is in the particular. "L'innovation est à craindre dans un Gouvernement, je n'en disconviens pas; mais ce n'est pas à dire qu'on doive s'abstenir de tout examen, \& que l'ancienneté soit un tître incontestable de bonté" (Anonymous, 1751b: 150). To the anonymous author (Baron de $\mathrm{M}^{* * *}$ ), the problem is not religion; it is rather human nature (individuals) that is to blame.

To another critic the issue is also individuals. A true religion is never the source of "dangerous innovation". The problem is the disciples. Yet, the writer introduces an argument that would become popular much later (Formey, 1756: 161):

Toute innovation est à craindre dans un Gouvernement? Quoi! Lorsqu'il y a des défauts essentiels, des abus crians, qui menacent un Etat de sa ruine, il vaut mieux que tout périsse que de hazarder une innovation. Je sais bien qu'en Politique il faut une grande circonspection; qu'il y a certaines choses qui pourroient mieux aller, mais dont la Réformation entraineroit des désordres pires que ceux qu'on se propose de réformer. Cependant, en Politique même, le mal peut se trouver tel qu'il ne puisse plus être dissimulé ni toléré.

By the 1760 s, many knew that Diderot was the author of the pamphlet. For example, a further critique which deserves mention, published anonymously again, refers to the Encyclopédie as containing from Diderot (not mentioned by name) a more credible source of information on Julian. This writer replies with the same kind of argument as Jean Henri Samuel Formey above (Anonymous, 1761: 254):

Est-il bien vrai, Monsieur, que toute innovation soit toujours à craindre? A parler en général, il seroit sans doute à souhaiter que tout gouvernement perséverat dans sa première constitution; parce qu'il n'est guères d'innovations qui ne causent un certain trouble ... Mais si le bien peut quelquefois dégénérer en mal, ne peut-on pas aussi convertir le mal en bien? Ce n'est qu’à force de changemens qu'on arrive à la perfection.

To the anonymous writer, innovation is progress (Anonymous. 1761: 254$55)$ :

C'est comme si [Diderot] disait que la création du jour a été une innovation funeste, 
\& qu'il eut mieux fallu demeurer dans une nuit éternelle. Chaque Législateur a innové, puisqu'il a donné des Loix nouvelles, \& prescrit une forme de gouvernement inconnue jusqu’à lui. Etoit-il plus expédient pour les peuples de rester dans leur état de rusticité \& de barbarie, que d'écouter des hommes qui leur dictoient des Loix propres à les civiliser $\&$ à leur procurer tous les avantages de la société?

I will return to this kind of argument later. Such an argument was very rare at the time. It was rather Bossuet's representation of innovation that got a hearing in France, including French politics. The debate in the National Assembly regarding the new constitution (1789) was in essence a debate on whether the constitution was to be a reformation of what was regarded as an existing constitution (or form of government) or inaugurating an entirely new constitution de novo, as Keith M. Baker puts it (Baker, 1990: 275). In the end, the French opted for the latter instead of tradition. ${ }^{7}$

Yet this debate was not conducted using the concept of innovation, in particular among the innovators themselves. No revolutionary thought of describing his project in terms of innovation. Innovation is a word, used by the critics of the revolution. When used, innovation is used without discussing its meaning. Above all, the denotation or criteria vary, depending on the speaker or writer. Two men may agree on the (lexical) meaning of innovation, yet they do not necessarily find the same things novel. To some, the General-Estates is an innovation, to others, no - except for the privilégiés "qui ne se plaignent que de l'esprit d'innovation" as Emmanuel Joseph Sieyès puts it in Qu'est-ce que le Tiers-État? (Sieyès, 1789: 101). To Jacques-Pierre Brissot de Warville, girondin assassinated, the General-Estates is rather a restoration (Brissot, 1989: 135). To some others the new constitution is an innovation - an "innovation hasardeuse" as stated by Jacques Necker, finance minister under Louis XVI (Necker, 1792: 351$)-{ }^{8}$ to others, no. To still others, like the clergy, a new mode of election with more equal representation to the people (one house rather than three Orders) is an innovation; to others, no. Only the Revolution is unanimously declared an innovation - as Burke does - at least by its critics. In fact, the analogy with or association between innovation and revolution abounds in the literature of the time. "La réforme conduit à l'innovation, l'innovation à la révolution, la révolution à l'anarchie et au désordre", such was the common opinion, as reported by Abbé Arthur Dillon in his Progrès de la révolution française en Angleterre (Dillon, 1792: 13).

Yet compared to England, very few titles on the "spirit of innovation" were produced in pre-revolutionary France. Nevertheless, the word appears in hundreds of documents, and the meaning is similar to that in England. The debates at the General-Estates of 1789 are quite representative of the representation of innovation. Innovation is used essentially by the critics of the Revolution. It serves to qualify the changes brought to the constitution as "dangerous" and 
to stress the nefarious ("alarmantes") effects of the Revolution. Every critic contrasts innovation, as Burke does, to custom. That no "innovation" be introduced that "would destroy or alter the essence of the monarchical government" is the message from Jean Marie Prudhomme, bookseller and author of over a thousand pamphlets, in his proposal for a constitution based on a summary of the Cahiers presented to the General-Estates (Prudhomme, 1789). To this end, Prudhomme stresses particularly that no innovation be introduced in the mode of representation of the three Orders.

In a similar vein, an anonymous writer produced a pamphlet on the "précautions à prendre contre les innovations présentées aux ÉTATS-GÉNÉRAUX”. The writer lists the "innovations dangereuses" brought into the mode of representation at the General-Estates that add up to a change to the "droit résultant des formes antiques et constitutionnelles" (Anonymous, 1789b: 7). The innovations "portent l'empreinte de l'ARBITRAIRE, qui est le fléau des Empires" (Anonymous, 1789b: 8). The three Orders, he claims, "n'entendent nullement être tenus de se conformer à ces innovations" (Anonymous, 1789b: 14).

Again, political representation is the issue discussed by the chevalier Marie Thérèse Léon Tinseau-D’Amondans in his Parallèle des deux déclarations du Roi. To the chevalier "Trois ans de crimes $\&$ de délire viennent de renverser cet empire florissant" (Tinseau-D'Amondans, 1792: 3). "Ce sont les innovations fondamentales qu'on y a faites [to the constitution], lors de la convocation des états-généraux, qui ont perdu le royaume" (Tinseau-D’Amondans, 1792: vii). The chevalier discusses four "innovations fondamentales" to "l'usage ancien \& constant de la monarchie" and concludes as follows: we must delay the discussion of "toute innovation qui a besoin d'essais, qui exige une longue discussion ou des rassemblements qui prolongés ne serviraient qu'à entretenir le mouvement \& l'agitation des esprits. Il faut attendre que cette fièvre politique soit calmée. Il ne s'agit pas d'améliorations ... Tout a été détruit; il faut commencer par tout rétablir" (Tinseau-D’Amondans, 1792: 47-48).

In contrast to the previous views, Guy Jean Baptiste Target, magistrate in the Parliament of Paris before the Revolution, argues for innovation in his L'Esprit des cahiers présentés aux États-Généraux. Written in the form of a law, with 693 articles, L'Esprit des cahiers sums up every matter discussed during the General-Estates: constitution, administration and law, commerce, public finance, religion, education. Yet Target avoids using the word innovation. All over the text, Target's keyword is regeneration (and revolution), not innovation. ${ }^{10}$ Target wants a "réforme absolue". "En général, les réformateurs se sont plus attachés à détruire qu'à édifier, à censurer les vices de l'administration qu'à les remplacer par une meilleure ... J'ai cherché en vain un édifice complet $\&$ détaillé" (Target, 1789: vi).

Yet in conclusion, Target admits to innovating: "Je m'attends qu'on me reproche de m'être livré dans cet écrit à l'esprit d'innovation, de l'avoir porté à 
l'excès ... De ce reproche je ne supprime que le mot excès, tout le reste est vrai" (Target, 1789: 493). To Target, to reform (regenerate) a corrupt state requires innovation. France wishes great changes ("ne demande-t-on pas à grands cris la régénération du royaume?") and the changes cannot be done without innovation. "J'ignore l'art de produire de très-grandes choses avec de très-petits moyens" (Target, 1789: 494).

When innovation is used by others than critics, it is normally used in a defensive mode. In a discourse pronounced before the National Assembly on June 17 1789, the revolutionary Honoré Gabriel Riquetti, comte de Mirabeau (1749-1791), claimed that liberty is not a matter of philosophy (science) or principles but of daily experience. Before outlining his own proposal for a declaration of rights, Mirabeau praises the American Declaration for such a pragmatism or middle ground, and at the same time minimizes any innovation in his own project. "Nous serons mieux entendus à proportion que nous nous rapprocherons davantage de raisonnements [simples]. S'il faut employer des termes abstraits, nous les rendrons intelligibles, en les liant à tout ce qui peut rappeler les sensations qui ont servi à faire éclore la liberté, et en écartant, autant qu'il est possible, tout ce qui se présente sous l'appareil de l'innovation" (Mérilhou, 1825: 208). Similarly, Gérard-Trophisme Lally-Tollendal, member of the Assemblée nationale constituante (as representative of the Lords), in a discourse to the Chambre de la noblesse (House of Lords) on 15 June 1789 states: "Et quant à cette expression d'innovation; quant à cette qualification de novateurs, dont on ne cesse de nous accabler; convenons encore que les premiers novateurs sont dans nos mains; que les premiers novateurs sont nos cahiers; respectons, bénissons cette heureuse innovation qui doit tout mettre à sa place, qui doit rendre tous les droits inviolables, toutes les autorités bienfaisantes, et tous les sujets heureux" (Lally-Tollendal, 1789: 164-65). ${ }^{11}$

Law holds the same pejorative view of innovation, that "goût léger du siècle" and "appât qu'employent les nouveaux docteurs" because it is "la manie de ceux [à qui] ils enseignent ... Ils peuvent ainsi combler leurs classes". So wrote a professor of law on the spirit of innovation in education (Dupin, 1808: 11819). Among several projects in the eighteenth century on the collection of ancient laws, the Recueil général des anciennes lois françaises, depuis l'an 420 jusqu'à la revolution de 1789 offers the following rationale for the study of past laws. In the introduction to volume one, François-André Isambert, lawyer and adviser to the King at the Cour de Cassation, reminds readers of the following two "cultures" of innovation - England and France (Jourdan et al., 1789):

Le mérite d'un législateur consiste moins à créer, qu'à profiter de ce qui est, pour asseoir un édifice durable et solide ... et cette manière de procéder est souvent préférable aux innovations. Nos voisins [England] ont leur raisons pour être plus attachés que nous à ces anciennes lois. Constitués de bonne heure, ils ont eu plutôt à 
défendre les anciennes maximes de leurs pères, qu'à courir après les innovations ... Aussi le cri des Anglais est-il aujourd'hui ... Nolumus leges Anglioe mutare. L'idée d'une réforme, quelque nécessaire qu'elle paraisse, éprouve dans ce pays une résistance presqu'invincible.

Chez nous, au contraire, l'esprit d'innovation a été permanent. Il a été favorisé par nos Rois ... mais l'impulsion était donnée: le peuple ... voulut, à son tour, conquérir un état politique, et participer au gouvernement; la révolution éclata; une constitution fut ... improvisée ...; la haine des anciennes institutions s'est montrée à un degré qu’on n’avait pas connu dans la révolution d'Angleterre.

To Isambert, that a ruler's main task is "creating new laws" and that France is imbued with the "spirit of innovation" are insufficient reasons for not studying past laws. "Mais, parce que le système de Louis XIV et de Louis XV, a fait place à un autre, conforme aux nécessités du siècle où nous vivons, est-ce donc une raison, pour que nous dédaignons l'étude des monumens des siècles passés?"

All in all, the representation of innovation that prevailed in 1789 is not different from that offered in the French Encyclopédie of 1751, itself a representation of centuries of uses of the concept: innovations are "difformités dans l'ordre politique", as the Table analytique et raisonnée des matières contenues in the Encyclopédie puts it (Diderot, 1780: 41). To the encyclopedists, innovation is a "nouveauté, ou changement important qu'on fait dans le gouvernement politique d'un état, contre l'usage $\&$ les règles de sa constitution". Innovation is contrasted to gradualism: "les révolutions que le tems amene dans le cours de la nature, arrivent pas-à-pas; il faut donc imiter cette lenteur" (Encyclopédie, 1774, Volume 30, art. Innovation: 757). Similarly, "novateur" - to the French "on ne dit pas innovateur: le mot usité est Novateur", suggests a dictionary of the time (Féraud, 1786) - is "toujours en mauvaise part" because men are attached to established things.

Yet at the same time, the representation of innovation began to change. The Encyclopédie admits both bad and good innovations: "Les novateurs en littérature peuvent corrompre ou perfectionner le gout; en religion, exciter ou calmer les troubles; en politique, sauver ou perdre une nation" (Encyclopedie, 1765, Volume 11, art. Novateur: 254). In the same volume, nouveauté (novelty) is defined as "tout changement, innovation, réforme bonne ou mauvaise, avantageuse ou nuisible". However, such a positive acknowledgment is timid. Echoing, or rather citing Francis Bacon, the Encyclopédie suggests that one should only accept innovation "peu à peu \& pour ainsi dire insensiblement" (Encyclopedie, 1765, Volume 11, art. Nouveauté: 265). "Il est bon de ne pas faire de nouvelles expériences pour accomoder un état sans une extrême nécessité $\&$ un avantage visible. Enfin, il faut prendre garde que ce soit le désir éclairé de réformer qui attire le changement, $\&$ non pas le désir frivole du changement 
qui attire la réforme" (Encyclopedie, 1765, Volume 11, art. Nouveauté: 266).

\section{Innovation and Instrumentality}

With time many people became conscious that innovation is first of all a word, a word used for polemical purposes. Innovation was not the subject of inquiry, study or theory. It was a linguistic weapon used against an enemy: the revolutionary, the republican and, in the nineteenth century, the socialist. "The word innovation is so extremely offensive, that like a harsh note in music, it is grating to the feelings of all who hear it: antiquity and old precedents are now in fashion, and must upon all occasions be quoted". So spoke Reverend Samuel John Nash in England in his Address to the Board of Agriculture on the Subject of Enclosure and Tithes (Nash, 1800: 2). To Nash, innovation is progress. "If ancient customs were always to be pleased, we might as well say that our military should be armed with bows and arrows, rather than fire arms" (Nash, 1800: 3). Nash proposes eliminating all vestiges that make people remember tithes, above all abolishing the term tithes itself.

Nash was right. The word innovation is offensive ... and much more. "On tremble au seul mot d'innovation "; ${ }^{12}$ a "mot maudit", as the fourierist Victor Considerant put it (Considerant, 1834: 312); "on abuse singulièrement aujourd'hui du mot innovation". ${ }^{13}$ To many, the "reproche d'innovation" is only a "préjugé", "une maxime de la stupidité et de la tyrannie", 14 "une crainte peu réfléchie", ${ }^{15}$ that of an "esprit borné". ${ }^{16}$ "From this appeal", concluded an anonymous writer, "there is no appeal" (Anonymous, 1844). ${ }^{17}$

Jean le Rond d'Alembert (1717-1783) summarizes the uses made of innovation perfectly. Innovation is a cry, "le cri de guerre des sots". In his Éloge de L'Abbé François Régnier Desmarais, (1786), d'Alembert asks why organizations [Corps] have "moins de sens $\&$ de lumières que les particuliers". It is because (Alembert, 1786: 293):

elles craignent le plus léger changement dans leurs principes, leurs opinions, leurs usages ... [D]ès qu'on propose une chose nouvelle, quelque raisonnable qu'elle soit, le cri de guerre des sots est toujours, c'est une innovation. Il n'y a, disait un homme d'esprit, qu'une réponse à faire à cette objection, c'est de servir du gland à ceux qui la proposent; car le pain, quand on a commencé d'en faire, était une grande innovation.

Innovation's rehabilitation came about due to many arguments, above all progress and utility. Thoughts on innovation as utility open an entirely new semantic field. From a focus on the past and the present (innovation as heresy and deviance), it was transformed and now allows one to talk about the 
future: innovation is an instrument for founding a new society and a new political order. ${ }^{18}$ Innovation is not harmful but useful. There are good and bad innovations. Beginning in the nineteenth century, the "dangerous innovation" turns into innovation with superlatives: the "Happy Innovation", the "Great Innovation". Innovation also gets "technicized". People start talking of "political innovation", "innovation in law", "linguistic innovation" instead of just innovation. This is a sign that people were appropriating a word in general use for more specific purposes.

The increasing use of innovation in a positive sense amounts to a perceived change in the world and a corresponding change in the conception of society. There occurs a "shift in the conception of time and a reorientation towards the future ... against which structural changes are perceived, evaluated and acted upon" (Richter, 1995: 35). Four characteristics of this change are: ${ }^{19}$

1. Pervasiveness. Change is everywhere, at least semantically (Koselleck, 1969; 1977): religion (Reformation), politics (revolutions), economics (industrial revolution), science (scientific revolution). While everything was perceived as continuous before, people now become conscious or aware of changes in every sphere of society. They accept change, even promote changes.

2. Rapidity. Change is radical and revolutionary. While it was previously thought that change is mainly gradual and evolutionary (Nisbet, 1969), change is now sudden. Revolutions become the emblem of change. ${ }^{20}$

3. Temporal dimension. Change is future-oriented, namely instrumental to social transformations rather than oriented to preserving the past. Change is productive (useful) rather than destructive (of customs) or, if destructive, is so in a positive manner. Radical change and revolutions announce new possible futures (Koselleck, 1969; Lüsebrink and Reichardt, 1988; Ozouf, 1989; Reichardt, 1997).

4. Source. Man becomes conscious of his own action. While change was previously explained by God, nature or necessity, man becomes aware of history and his capacity to shape his own destiny (Koselleck, 2002a).

Such changes could not but be named using new words, or re-descriptions of existing words. ${ }^{21}$ Such is the case with innovation. Words are semantic conditions (factors) of events, as much as indicators of history (Koselleck, 2002b). They are an integral part of the event, a crucial ingredient of its happening. First, words give significance to events. Second, words articulate new possibilities (Sewell, 2005: 245-51).

After 1789, one central argument on innovation develops that gave the concept a positive connotation. Innovation is discussed in terms of progress, as Nash did (see p. XX above): "If it had not been for this happy spirit of innova- 
tion, what would be the state of mechanics, mathematics, geography, astronomy, and all the useful arts and sciences" (Pigott, 1792: 171). On the one hand the literature on progress, including encyclopedias and dictionnaires critiques, starts using "innovation" in a positive sense - such was not the case during the previous century (the Encyclopedists, Nicolas de Condorcet, Anne Robert Jacques Turgot). On the other hand, the discourses on innovation begin making use of "progress", thus contributing to make honourable what was, until then, an odious word (innovation). As Robert Nisbet puts it, like Auguste Javary before him, ${ }^{22}$ after 1750 progress is the dominant idea, the "developmental context for other ideas" (Nisbet, 1980: 171; Koselleck, 2002b).

Innovation as progress is understood as utility. Innovation is essentially what is useful or productive of good effects: the improvement of the material conditions of men, but also their political and social conditions. Bentham offered a full-length argument here (Godin, Forthcoming-B). Yet, the argument existed before him. For example, Guillaume Cave (16??-1713), an English doctor of theology and chaplain of Charles II, included a chapter on "De l'innovation qui étoit imputée au Christianisme" in his La religion des anciens Chrétiens, dans les premiers siècles du Christianisme (1671), translated into French in 1711. Cave offers two arguments against those who "font passer la religion Chrétienne pour une religion moderne \& qu'on venoit d'inventer" (Cave, 1671: 19). One argument is to the effect that all things that exist were new at their beginning. The other argument is progress: "Il est sans contredit naturel à l'homme, de préférer le meilleur au moindre, ce qui est utile à ce qui ne l'est pas". ${ }^{23}$

Another such pre-revolutionary use is from Robert Robinson (1735-1790), an eminent English dissenting divine and Baptist minister, whose political views caused some concern in the Church - but were cited by Burke. In a pamphlet published in 1782, Robinson looks at the principles guiding the many petitions to Parliament asking for changes and new laws. To Robinson, the controversies (religious and political) that divide England rest on mistakes. One of the true principles guiding the petitions is innovation. There is "necessity of reforming abuses at all times, and in all places, where they are found, without being frightened at the din of novelty, novelty" (Robinson, 1782: 62-63):

Innovate! England ... has done nothing but innovate ever since the reign of Henry the seventh .... She has imported the inventions and productions of the whole earth, and has improved and inriched herself by so doing. New arts, new manufactories, new laws, new diversions, all things are becoming new ... The truth is human knowledge is progressive, and there has been a gradual improvement in every thing; this age knows many things the last was ignorant of, the next will know many unknown to this, and hence the necessity of frequent innovations ... The love of novelty is so far from being dangerous, that it is one of the noblest endowments of 
nature. It is the soul of science, and the life of a thousand arts.

As the nineteenth century progressed, such uses of innovation multiplied - including in religion. ${ }^{24}$ France was no exception. Echoing the anonymous replies to Diderot: "Où en serions-nous, hélas! si nos ancêtres avaient eu pour les leurs l'aveugle vénération que l'on exige de nous pour les préjugés antiques? L'homme serait encore sauvage", claimed Pierre-Henry Thiry Holbach Dumarsais in his Essai sur les préjugés (Dumarsais, 1822: 143). Similarly, to Abbé Guillaume-André-René Baston, vice-president of the Academy of Sciences of Rouen: "L'innovation ne sert pas seulement à détruire ce qui est mauvais ou faux; elle sert aussi à perfectionner ce qui est bon et vrai .... Ce n'est qu'à force d'innovations que les premières productions du génie acquièrent de la consistance, une juste étendue, des proportions régulières" (Baston, 1810: 133).

Auguste Comte too uses innovation in a positive sense in several of his writings (Cours de philosophie positive; Système de politique positive ou Traité de sociologie). Comte contrasts "esprit de conservation" to "esprit d'innovation" as two fundamental instincts and explains social progress as the result of the later: "L'évolution sociale eût été certes infiniment plus rapide que l'histoire ne nous l'indique, si son essor avait pu dépendre surtout des instincts les plus énergiques; au lieu d'avoir à lutter contre l'inertie politique qu'ils tendent spontanément à produire dans la plupart des cas" (Comte, 1839: 559). Similarly, François Laurent, jurist, historian and professor at Université de Gand (Belgium), discusses the "idea of progress" over 80 pages in his Etudes sur l'histoire de l'humanité. Laurent compares religion (or rather the Church) to science, in which progress is the distinctive characteristic because of innovation. "Comment y aurait-il progrès sans changement, sans innovation" (Laurent, 1866: 85). Laurent claims that the Church innovates too, but unconsciously. "Tout ce qui est nouveau est hérétique. C'est cette maxime que Bossuet oppose sans cesse aux protestants ... Il y a, quoi qu'on dise, innovation mais on la cache ... $\mathrm{Si}$, malgré tout, le progrès se réalise, c'est en quelque sorte en cachette; on le nie au besoin" (Laurent, 1866: 85).

Whether one writes on religion, politics, history, science or arts, in books or magazines, innovation gets rehabilitated in the name of progress and utility. In 1850, the Académie des jeux floraux launched a prize for an essay on Caractériser la double influence de la force de l'habitude et de l'amour de la nouveauté, et expliquer leur action respective sur les moeurs, l'état social et la littérature. The winner, Gabriel de Belcastel, compares Asia which is in "a state of petrification" to Europe and France, people "apôtre de la loi nouvelle ... et poussée sans cesse en avant" by innovation. "Lesprit d'innovation ne doit pas être le dédain irréfléchi des coutumes, mais l'étude sérieuse et calme des progrès à réaliser" (Belcastel, 1850: 19). 
Let's take one more example, this time from politics. In 1866, J.-M. Dubeuf, voyageur de commerce, published a Revue rétrospective des principaux faits et innovations et événements acquis depuis le règne de Napoléon III. Because of the "règne glorieux" of the Emperor, states Dubeuf, "le drapeau de la France représente partout la civilisation et le progrès" (Dubeuf, 1866: 14). Dubeuf attributes six great innovations to Napoléon: universal suffrage, public services, free trade ("l'innovation la plus hardie et la plus radicale entre toutes de notre siècle"), securalization, civilization (wars "mettent à la raison des peuples à demi-sauvages") and European diplomacy. "Aveugles seraient ceux qui nieraient", claims Dubeuf, "les bienfaits que tirera l'humanité de ces grandes phases politiques au profit de son émancipation sociale" (Dubeuf, 1866: 16).

These are just a few examples, among many. Innovation is recognized as a fact of life; it is present in every sphere of society; it is praised for its radical or revolutionary effects. Innovation is revolution in a positive sense, and revolution is innovation. "L'innovation, mais l'innovation en grand, l'innovation qui annonce qu'on est entré dans une ère nouvelle de la pensée, déborde de partout, dans les livres, dans les journaux, dans les chaires de philosophie, et jusque dans la Chambre des députés", claimed the Revue encyclopédique, ou Analyse raisonnée des productions les plus remarquables dans les sciences, la politique, l'industrie et les beaux-arts, published by $\mathrm{H}$. Cornot and P. Leroux (1832). In the opening prospectus of the Tablettes universelles, a monthly magazine of the nineteenth century on French society and history, the editors attribute the spirit of innovation of the time to the Revolution (Aumond and Gouriet, 1834):

L'époque actuelle ne ressemble à aucune de celles qui l'ont précédée ... infatigable activité des esprits, bruyant essor de la pensée et de la presse ... La liberté, reconquise pas tout un peuple, a réveillé, ranimé, électrisé toutes les imaginations ... Les sciences, la littérature, les beaux-arts et surtout l'art dramatique, ne marchent que par systèmes et par innovations; jamais l'esprit humain ne montra peut-être une pareille agitation en tous sens ... [Ce] mouvement incessant [a été] autorisé et excité [par the Révolution].

The "spirit of innovation" is now one of praise. Both the Reformation and the Revolution are innovation because they are progressive, claimed Laurent. ${ }^{25}$ "La réforme serait une innovation ... Voilà ce que Bossuet ne cesse de dire ... Sur ce terrain Bossuet est invinsible ... Toute révolution est une innovation ... Il faut abandonner aux utopistes l'espoir d'un progrès régulier et sans entraves". Innovation is pervasive, perhaps too pervasive (Laurent, 1879: 13-14):

L'humanité est en révolution permanente; l'innovation est une condition de son existence; du jour où elle serait immuable, elle périrait ... Le siècle dans lequel nous 
écrivons a été si fécond en révolutions, que le mot d'innovation qui effrayait tant Bossuet, est entré dans nos idées et nos sentiments habituels; nous avons plutôt à nous garder d'un autre écueil, c'est d'applaudir aux révolutions par cela seul qu'elles sont des innovations, ou de mal juger le passé, par amour pour les nouveautés.

In the nineteenth century, innovation holds such an exalted place in a growing number of texts. Among the terms and expressions used to talk of innovation as a new epoch are: âge d'innovation, siècle d'innovation. Innovation becomes revolutionary in a positive sense: révolution permanente, révolution totale, bouleversement, changement radical, innovation révolutionnaire, profonde et radicale, importante, grave et profonde, hardie, téméraire, brusque. The innovation is praised for its benefits: grande et heureuse, intérêt public, utilité, incontestables avantages, progrès.

Two usages or contributions to the new connotation should be mentioned. First, "social innovation". In the 1830s, innovation got a social connotation. At a time when socialism was the "new spiritual power" (Gellman-Jones, 2010) as a result of the 'failures' of the French revolution - schemes of social reform came to be called social innovation because of their revolutionary benefits to the people. To the disciples of the French utopian Charles Fourier, social innovation is most desired: "On sent que la société est mal à l'aise", wrote Victor Considerant in a book whose purpose was to contribute to the diffusion of Fourier's "grande conception". "On admet que [la société] a besoin d'une organisation nouvelle. L'état des choses actuelles enfante désordre sur désordre, perturbation sur perturbation, et tout cela ne peut évidemment cesser que par une innovation sociale" (Considerant, 1834: 312).

The second contribution to the positive connotation of innovation is in science and arts. Innovation in science was as contested as in religion and politics until then. While most of the titles on innovation in the seventeenth and eighteenth century are concerned with religion and politics, many now deal with science, or rather applied science, namely the practical and useful, as contrasted to the speculative or theoretical, as the Dictionnaire des sciences médicales puts it in a long article (20 pages) titled Innovation, whose purpose was to "réfléchir sur le mot innovation appliqué à la médecine". "Comment se fait-il", asked the authors, "que l'art de guérir voit ses théories et ses méthodes changer tous les jours?" (Dictionnaire, 1818: 237). The article sketches the history of medicine as progress from speculation to facts, distinguishes kinds of innovations ${ }^{26}$ and makes a plea for innovation of a practical kind ("traitement des maladies et méthodes cliniques").

Like social innovation, such use of innovation in science and arts occurred a century before uses in industry. The connotation has nothing to do with what we now call "technological innovation". Yet both social innovation and innovation in science and arts - every type of innovation, in fact - remain contested 
over the nineteenth century. The positive uses share place with the negative and the accusatory. Innovation only developed a dominant positive connotation in the second half of the Twentieth century.

Let's conclude with what is, to the best of my knowledge, the first 'theoretical' thought on innovation: John Patterson's Innovation Entitled to a Full and Candid Hearing. This is a long analysis (60 pages), of a psycho-social kind, in three parts, published in New York in 1850. To Patterson, innovation is progress or newly-discovered truths, and the innovator is a reformer, with a moral mind (a liberal). "The cry of 'innovation' and 'infidelity' arise, almost as loud ... as that of heresy in the darker ages of the world ... The effect of such a course of discipline is to put an effectual stop to all progress in the knowledge of truth" (Patterson, 1850: 19-20). Patterson begins his analysis with "examples of past resistance to novelty and change", from Socrates to Christ, Luther and Calvin, from Columbus to Descartes, Galileo, Newton, Harvey, Fulton and may others. "No man who attacks the errors of his age, and proposes reform, can escape the ordeal of persecution. He is regarded by his contemporaries as a dangerous character, an overturner of society, philosophy, or religion, a fanatic, a heretic, a dreamer, a madman, a fool, and richly deserving, if not summary punishment, at least the unmeasured contempt of a wronged and insulted world" (Patterson, 1850: 37).

Then Patterson distinguishes the "reformer" and the "anti-reformer" - innovation is used mainly to discuss opposition to innovation by anti-innovators, while reform is used to discuss innovators. For each class, Patterson devotes a part of the work and develops an analysis of the character of the men (see Annex). The anti-innovator is of two kinds: passive (neutral) and active. He "does not oppose what is novel, because it is right or wrong, but merely because it is new" (Patterson, 1850: 52). The anti-innovator has a bias against newly-discovered truths because of "fear of popular disgrace", envy and "desire to please the multitude". Patterson reduces all the causes of opposition to innovation to three: 1. Ignorance; 2. Prejudice or passion; 3. Policy or interest.

In contrast, the innovator is a man "of original genius" who advances "beyond the beaten paths of other days, and perceive[s] the dawn of light which ha[s] never arrested the attention of his fellow-man" (Patterson, 1850: 22). The innovator is open-minded and progressive: "He rejects nothing new because it is new ... and clings to nothing old because it is old" (Patterson, 1850: 41).

Patterson's analysis includes (almost) every kind of innovation (except the political): religion, philosophy, science and arts (steam-engine, lighting) and travel. To be sure, Patterson's study of innovation is loaded with moral values. Yet it remains an original work at a time when innovation was an under-studied concept. It was not until French sociologist Gabriel Tarde's time that the next theoretical work on innovation appeared (Tarde, 1890). 


\section{Conclusion}

Innovation emerged as a descriptive concept with diverse meanings (Godin, Forthcoming-A). To ancient Greeks it referred to change in the established order, particularly political changes. To Latin writers (IV-XVth century), it meant (spiritual) renewal. Yet, from the Renaissance to the Eighteenth century, the concept shifts to the accusatory. It then takes on different meanings, depending on the accuser. Innovation is rarely defined as such. ${ }^{27}$ Most writers use it as a linguistic weapon against their enemy. Innovation is a word used to exploit emotions, to insult, to hurt and make, as do many other words, "the enemy odious or contemptible by asserting he was like somebody or something we already disliked or looked down on" (Lewis, 1960: 323). Lewis speaks of a "tendency to select our pejorative epithets with a view not to their accuracy but to their power of hurting ... not to inform ... but to annoy" (Lewis, 1960: 326). A "word is selected solely because the speaker thought it was the one that the enemy (if he could hear it) would most dislike". The use of words is tacti$\mathrm{cal}$ - and emotional. It is an attempt to appropriate from one side (praise), and deny to the other (disapproval) a potent word.

Then, during the Nineteenth century, innovation got rehabilitated gradually because it was instrumental to progress, and gave rise to a theoretical concept in the next century. The pejorative or dyslogistic use of pre-revolutionary France gave way to the superlative or eulogistic. Blame shifted to praise. The word innovation enlarges its meaning and becomes, to use Koselleck's conception (Koselleck, 1972), a concept used to talk of experienced and expected changes, including those which were denied before. Change in the meaning of innovation was a response to a new (linguistic) context. ${ }^{28}$ Self-consciousness or creativity (man as maker of history), belief in progress (in the political, social and material conditions of men) and later, economic growth (through technology) led to a rehabilitation, then to a shared (or rather dominant) understanding of innovation.

In his study on the idea of happiness in the eighteenth century, Robert Mauzi suggests that some ideas belong "à la fois à la réflexion, à l'expérience et au rêve" (Mauzi, 1979: 9). Before the Ninetieth century, the idea of innovation belonged to experience, but very rarely to thoughts and dreams. The innovator himself makes no use of the word. Innovation is a word used by the critics. The innovation of the Nineteenth and Twentieth century is to enrich the idea of innovation with thought (theory), dreams and imagination, thanks to "technological innovation" (economics and public policy). Innovation takes on a positive meaning that had been missing until then, and becomes an obsession. 


\section{Endnotes}

1 Special thanks to Pierre Lucier, Apostolos Spanos and Vasileios Syros for commenting on a first draft of this paper.

2 For an example of abuse, see Goulemot (1968) on the word revolution.

3 Gerhart B. Ladner pointed to the same issue in The Idea of Reform: "though slight in themselves, [the peculiarities of the terminology of reform] are of some weight if held together" (Ladner, 1959: 133).

4 Neither has "innovation studies" to which innovation is essentially an 'economic' concept: (technological) innovation is the source of economic growth.

5 Edward VI (England and Wales, 1548), Henri III (Navarre (Henri III, 1586; 1589), Elizabeth (England and Wales, 1589; 1602), James I (England and Wales, 1603a; 1603b), Charles I (England and Wales, 1626; 1628; 1638; 1641), Louis XVI (1775).

6 One may find occurrences of positive uses before 1789, but they are very rare compared to the pejorative.

7 On the thesis that the goal of the French revolutionaries was restoration (of rights and liberties) rather than innovation, see Arendt (1963). On the opposite thesis, see Dippel (1976) on the American revolution.

8 The new French constitution is a source of anarchy ("vingt-six millions de Souverains"), as opposed to the English model. "C'est une entreprise hasardeuse que de vouloir porter une innovation politique à l'extrême; $\&$ c'est une entreprise singulière, que d'exécuter ce plan sans aucun sentiment profond" (Necker, 1792: 35051).

9 1. "la double représentation accordée au tiers-état, donnant à celui-ci une supériorité de suffrages au détriment des deux autres ordres"; 2. "la réunion des États-Généraux en une assemblée unique, assurant ainsi une majorité au tiers-état"; 3. "les pouvoirs illimités données aux députés (voter selon leur conscience et intérêt et droit de ne pas reconnaitre la décision adoptée à la majorité), en lieu et place des mandats impératifs"; 4. "l'innovation que sont les États provinciaux (par rapport à un pouvoir unique)".

10 On regeneration, see Baecque (1988).

11 Twenty-five years earlier, Jean-Jacques Rousseau too used the word innovation while discussing the veto. "Il n'y eut jamais un seul Gouvernement sur la terre où le Législateur enchaîné de toutes manières par le corps exécutif, après avoir livré les Lois sans réserve à sa merci, fut réduit à les lui voir expliquer, éluder, transgresser à volonté" (Rousseau, 1764: 156). Rousseau makes uses of innovation only because the anonymous author he criticizes does so. To the anonymous author a veto is a safe measure against innovations to the constitution. To Rousseau, this is the most subtle fallacy. It is rather a government that innovates: "Qui est-ce qui peut empêcher d'innover celui qui a la force en main, \& qui n'est obligé de rendre compte de sa conduite à personne? ... Celui qui a la Puissance exécutive n'a jamais besoin d'innover par des actions d'éclat. Il n'a jamais besoin de constater cette innovation par des actes solennels. Il lui suffit, dans l'exercice continu de sa puissance, de plier peu à peu chaque chose à sa volonté" (Rousseau, 1764: 158-59). 
12 Gaspard-Louis Rouillé d'Orfeuil, intendant under the Old regime, in his philosophical and political 'dictionary' L'alambic des Loix (Chapter Innovation). One should distinguish innovation as artifice coming from a "source empoisonnée" or an interested party, from an innovation which is "le fruit d'un long travail, \& d'une experience réfléchie" (Rouillé d'Orfeuil, 1773: 76).

13 Cyprien Desmarais, royalist writer, on the querelle between classicism and romanticism. Romanticism is "un être tout libéral", an "innovation". Yet "on abuse singulièrement aujourd'hui du mot innovation, introduit dans le langage politique. Il est évident que le libéralisme, qui prétend vivre d'innovations, ne devroit appeler de ce nom que les innovations qui peuvent avoir pour lui des conséquences fécondes; or, comment peut-il réclamer, comme étant de son domaine, une innovation [romantisme] qui le tue" (Desmarais, 1826: 116).

14 Pierre-Henry Thiry Holbach Dumarsais in his Essai sur les préjugés. "L'antiquité donne toujours du poids et de la solidité aux opinions des hommes ... Ils s'imaginent que ce que leurs ancêtres ont jugé convenable ne peut être ni altéré ni anéanti sans crime et sans danger ... Ils s'en rapportent aveuglément aux décisions de ceux qui sont plus âgés qu' eux ... Il ne faut rien changer ... toute innovation est dangereuse" (Dumarsais, 1822: 141-42). "Ne rien changer, ne rien innover, sont des maximes ou de la stupidité ou de la tyrannie" (Dumarsais, 1822: 143).

15 Isaac Beausobre, Calvinist divine and ecclesiastical writer, in Introduction générale à l'étude de la politique, des finances et du commerce: "S'il est déraisonnable de laisser le gouvernement des affaires à ces hommes qui passent leur vie à faire des projets; il l'est autant de ne jamais écouter ceux qui proposent de nouvelles vues, \& de s'en tenir à ce qui se pratique, dans la crainte peu réfléchie du danger des innovations" (Beausobre, 1791: 52).

16 In the frontispiece to Louis-Sébastien Mercier's Fragments de politique et d'histoire: "Innovation, innovation! dit ou répète un esprit borné. Oh! C'est bien l'erreur qui est nouvelle auprès de l'ordre éternel des choses" (Mercier, 1792).

17 Similar accusations abound in England: cry of innovation, disease of the mind, deadly poison, conduct worthy of children.

18 To be sure, there was a future-oriented perspective before the sixteenth century. Yet it was eschatological rather than teleological. See Koselleck (1968).

19 On early representations of change, see Nisbet (1969), particularly pp. 166-88. Nisbet analyzes the representations or theories of change according to six characteristics: natural, directional, immanent, continuous, necessary and proceeding from uniform causes. Burnett and Palmer (1967) also offer a typology of characteristics of changes - rapidity (rapid versus gradual), pervasiveness (total versus piecemeal or none), time (future: utopian ideal; versus past/present: classic ideal).

20 "Tout est révolution dans ce monde" (Louis Sébastien Mercier; cited in Koselleck, 1969: 48); "Le monde se conduit par des révolutions continuelles" (Gabriel Bonnot de Mably; cited in Baker, 1988: 47); "My dear philosopher, doesn't this appear to you to be the century of revolutions?" (François-Marie Arouet Voltaire, in a letter to d'Alembert; cited in Baker, 1990: 203); "Les révolutions sont nécessaires, il y en a toujours eu, et il y en aura toujours" (Denis Diderot, Encyclopédie).

21 On some concepts of change (called concepts of "movement"), see Koselleck (1977). 
22 "L'idée de progrès ... conçue comme loi générale de l'histoire et de l'avenir de l'humanité ... appartient en propre à notre siècle" (Javary, $1851: 1$ ).

23 According to Cave, the Christian writer Arnobe (c.240-304) says: "de grace, quel tort cela nous fait-il [que notre religion soit nouvelle]? Ne pouvons nous pas reprocher le même défaut aux premiers tems du monde, que les gens vivoient pauvrement $\&$ miserablement, jusqu'à ce qu'ils soient peu à peu parvenus à une maniére de vie plus magnifique $\&$ plus illustre ... Il est sans contredit naturel à l'homme, de préférer le meilleur au moindre, ce qui est utile à ce qui ne l'est pas" (Cave, 1671: 28-29). Second, according to Cave again, Saint-Ambroise (340-397) says: "Vous dites que nôtre religion est nouvelle, $\&$ la votre ancienne, mais ... si la nôtre est nouvelle, elle vieillira avec le tems, \& la vôtre qui est, dites vous, ancienne, a été nouvelle pendant un certain tems. Il ne faut mesurer ni la bonté ni la dignité d'une religion au tems qu'elle a duré, mais à l'excellence de son culte" (Cave, 1671:30).

24 For an example of rehabilitation of innovation in religion, see Finney (1835). In a series of Friday sermons on his return from Europe, the American pastor Charles Finney found that "the spirit of revival had greatly declined in the United States". Finney argues that for a revival of religion to occur there must be innovation. Over the centuries, states Finney, the Church has done nothing but innovate (a "succession of innovations", "by degrees"). God has imposed no rules in matter of discipline and ceremony. It is left to men to innovate. Yet, "in the present generation, many things have been introduced which have proved useful, but have been opposed on the ground that they were innovations" (Finney, 1835: 242). Finney claims that "without new measures it is impossible that the church should succeed in gaining the attention of the world of religion ... Novelties should be introduced no faster than they are really called for ... But new measures we must have (Finney, 1835: 251-52).

25 Interestingly for the time, Laurent defends an evolutionary view on innovation. Every revolution "a ses racines dans le passé" (Laurent, 1879: 10). "Nous ne dirons pas que sans Luther il n'y aurait pas eu de réforme; tout était mûr pour une révolution". Men of genius are only "l'expression de l'état social dans lequel ils vivent" Laurent, 1879: 17). "Les plus grands des révolutionnaires ne sont pas les novateurs proprement dits; ceux-ci se bordent d'ordinaire à formuler les voeux des peuples, souvent en les exagérant; les vrais novateurs sont ces hommes obscurs" (Laurent, 1879: 21). In social matters, the reformation "n’a pas innové, elle n'a fait que continuer le mouvement des idées qui s'étaient fait jour pendant le moyenâge" (Laurent, 1879: 29).

26 "Les innovations produites par l'esprit de système", "les innovations qui sont le résultat d'une observation plus attentive et de faits mieux étudiés" et les "innovations venues de procédés perfectionnés, de remèdes introduits, de pratiques adoptées" (Dictionnaire, 1818: 254-55).

27 One exception is Baston. In his discourse before the Academy of Sciences of Rouen in 1809, Baston attempts to "fixer le sens du mot innovation" and distinguish innovation from other words like novelty, renewing, change and variation. "Il n'en est pas un seul qui lui ressemble exactement. La nouveauté n'est pas toujours de l'innovation; le renouvellement en approche davantage, mais n'y atteint pas; le changement n'en est que la moitié; la variation est plus mobile qu'elle" 
(Baston, 1810: 130). Baston concludes: "pour qu'il y ait innovation, il faut que la chose remplacée par une chose nouvelle, ait été, dès l'origine, ce qu'elle fut en finissant, ou qu'elle ait eu une si longue durée, que ce qui avait été avant elle, soit presqu'entièrement oubliée" (Baston, 1810: 131).

28 This paper has concentrated on discourse. I leave to the historians of innovation the study of facts behind the discourse.

\section{Sources (before c.1900)}

ALEMBERT, Jean le Rond d' (1786), Histoire des membres de l'Académie française, morts depuis 1700 jusqu'en 1771, pour servir de suite aux éloges imprimés \& lus dans les Séances publiques de cette Compagnie, tome 3, Amsterdam: Moutard.

ANONYMOUS (1747), Pensées chrétiennes mises en parallèle, ou en opposition avec les Pensées Philosophiques. On y a joint quelques REFLEXIONS d'un autre Auteur sur ces dernières, Rouen, aux dépens de la compagnie.

ANONYMOUS (1751a), Pensées anti-philosophiques, La Haie: Pierre van Cleef.

ANONYMOUS (Baron de ***) (1751b), Refutation des Pensées Philosophiques, par les seules lumières de la raison et les principes de la saine philosophie, Amsterdam: Werstins \& Smith.

ANONYMOUS (1761), La religion vengée ou réfutation des auteurs impies; dédiée à Monseigneur Le Dauphin, Société de gens de Lettres, Paris: Chaubert; Herissan.

ANONYMOUS (Comte de $\mathrm{M}^{* * *}$ ) (1789a), L'innovation utile, ou la nécessité de détruire les Parlements: Plan proposé au Roi, La Gazette infernale, Paris.

ANONYMOUS (1789b), Motifs et exemples de précautions à prendre contre les innovations du réglement de l'instruction, óc, Publiés pour la convocation des ÉTATS-GÉNÉRAUX, Paris.

ANONYMOUS (Decius) (1844), Innovation, Part VI and VII of a series of articles entitled Pickings from Common Bones, The Universalist Union, 9 (6): 388-90 and 404-406.

AUMOND, Louis and Jean-Baptiste Gouriet (1834), Nouvelles tablettes universelles, histoire de France contemporaine. générale et progressive. Ouvrage ouvert à toutes les opinions, croyances, doctrines et innovations de l'époque; continuant les Tablettes $\mathrm{Na-}$ tionales [1820s] dans leur spécialité politique ..., Morinval: Pihan Delaforest.

BACON, Francis (1620), Francisci de Verulamio, Summi Angliae Cancellarii, Instauratio magna, Londini: Apud [Bonham Norton and] Ioannem Billium typographum regium.

BASTON, Guillaume-André-René (1810), Réponse aux Discours de MM. Blanchemain, Bonnet, Boismare et de Lancy, in Précis analytique des travaux de l'Académie des sciences, belles-lettres et arts de Rouen pendant l'année 1809, Compte-rendu de MM. les Secrétaires, Rouen: P. Perriaux: 129-37.

BEAUSOBRE, Isaac de (1791), Introduction générale à l'étude la politique, des finances et du commerce, volume 2, Brussels: B. Le Francq.

BELCASTEL, Gabriel de (1850), Discours au concours de l'Académie des jeux floraux, Toulouse: Typographie de Bonnal et Gibrac.

BOSSUET, Jacques-Bénigne (1688), Histoire des variations des Églises protestantes, Pa- 
ris: Guillaume Desprez et Jean Desessartz.

BRISSOT, Jacques-Pierre (1782), De la vérité, ou méditations sur les moyens de parvenir à la vérité dans toutes les connaissances humaines, nouvelle édition, Neuchatel: Société typographique [1792].

BRISSOT, Jacques-Pierre (1789), Plan de conduite pour les députés du peuple aux ÉtatsGénéraux de 1789, Paris.

BUILLIARD, Pierre (1783), Dictionnaire élémentaire de botanique, édition refondue par Louis-Claude Richard [1800], Paris: Librairie d'Éducation et des Sciences et Arts.

BURKE, Edmund (1790), Reflections on the Revolution in France, New York: Dover [2006].

CARNOT, H., and P. Leroux (1832), Revue encyclopédique, contenant l'analyse des productions les plus remarquables dans les sciences, la politique, l'industrie et les beauxarts, Paris: Bureau de la revue encyclopédique.

CAVE, Guillaume (1673), De l'innovation qui étoit imputée au Christianisme, in G. Cave, La religion des anciens Chrétiens, dans les premiers siècles du Christianisme, Volume 1, Amsterdam: Jaques Desbordes [translation from English: 1711]: 18-33.

COMTE, Auguste (1839), Cours de philosophie positive, Volume 4, Paris: Bachelier.

COMTE, Auguste (1841), Cours de philosophie positive, Volume 5, Second Edition, Paris: Ballière et Fils [1864].

CONSIDERANT, Victor (1834), Destinée sociale, Volume I, Paris: Librairies du Palais-Royal.

CONSIDERANT, Victor (1842), Bases de la politique positive; Manifeste de l'École sociétaire, fondée par Fourier, Second edition, Paris: Bureaux de la Phalange

DEFOE, Daniel (1702), Essays upon several projects: or, effectual ways for advancing the interest of the nation. Wherein are plainly laid down. The Means by which the Subjects in general may be eased and enriched; the Poor relieved, and Trade encreased in the most material Branches of it, viz. in Constituting Seamen to theirs and the Nations Advantage for Encouragement of Merchants and Merchandizing; for Relief of the Poor of Friendly Societies; for discouraging Vice, and encouraging Vertue; the Usefulness; of Banks and Assurances; to prevent Bankrupts; with the surest way to recover bad Debts; and many other considerable things, profitable and conducing to the great Advantage of the Nation in general, London: printed for Thomas Ballard, at the Rising Sun in Little Britain.

DESMARAIS, Cyprien (1826), Le temps présent, ou essais sur l'histoire de la civilisation au dix-neuvième siècle, Paris: Ladvocat, Ponthieu.

DICTIONNAIRE des sciences médicales, par une Société de médecins et chirurgiens (1818), Innovation, Paris: C. L. F. Panckoucke: 236-55.

DIDEROT, Denis (1746), Pensée philosophiques, La Haye, aux dépens de la Compagnie.

DIDEROT, Denis (1780), Table analytique et raisonnée des matières contenues dans le XXXIII volumes in-folio du Dictionnaire des sciences, des arts et des métiers, et de son supplément, Tome second, Paris: Panckoucke.

DILLON, Arthur (1792), Progrès de la révolution française en Angleterre, Paris: Gattey.

DUBEUF, Jean-Marie (1866), Revue rétrospective des principaux faits, innovations et événements acquis à l'histoire depuis le règne de Napoléon III, Caen: Emile Alliot et Co. 
DUMARSAIS, Pierre-Henri Thiry Holbach (1822), Essai sur les préjugés, ou de l'influence des opinions sur les moeurs et sur le bonheur des hommes, Paris: Niogret.

DUPIN, André-Marie-Jean-Jacques (1808), De l'esprit d'innovation et son application dans l'enseignement du droit, in Bibliothèque choisie à l'usage des étudiants en droit, ou Notice des Livres de Droit qui leur sont les plus nécessaires, Paris: Durand: 118-20.

ENCYCLOPÉDIE, ou dictionnaire raisonnée des sciences, des arts et des métiers, Lausanne: Sociétés typographiques, Volume 11 (1765) and Volume 30 (1774).

ENGLAND AND WALES. Sovereign (Edward VI) (1548), A proclamation against those that doeth innouate, alter or leaue doune any rite or ceremonie in the Church, of their priuate aucthoritie: and against them which preacheth without licence, set furth the .vj. daie of Februarij, in the seconde yere of the Kynges Maiesties most gracious reigne, Excusum Londini: In aedibus Richardi Graftoni regij impressoris. Cum priuilegio ad imprimendum solum.

ENGLAND AND WALES. Sovereign (Charles I) (1626), By the King. A proclamation for the establishing of the peace and quiet of the Church of England, [Imprinted at London: By Bonham Norton and Iohn Bill, printers to the Kings most excellent Maiestie.

ENGLAND AND WALES. Sovereign (Charles I) (1628), His Maiesties dclaration [sic] to all his louing subiects, of the causes which moued him to dissolue the last Parliament published by His Maiesties speciall command, Imprinted at London: By Bonham Norton and Iohn Bill.

ENGLAND AND WALES. Sovereign (Charles I) (1638), Charls by the grace of God, King of Scotland ...: for-sa-meikle as we are not ignorant of the great disorders which haue happened of late within this our ancient kingdome of Scotland, occasioned, as is pretended, vpon the introduction of the service booke, booke of canons, and high commission, thereby fearing innovation of religion and laws ..., Given at our court of Greenwich, the twentie eyght day of June, and of our reygne the thirteenth yeare. Reproduction of original in the Town House (Aberdeen, Scotland). Charter Room.

ENGLAND AND WALES. Sovereign (Charles I) (1641), The King's Proclamation on Religion, in S. R. Gardiner, The Constitutional Documents of the Puritan Revolution, 1625-1660, Oxford: Clarendon Press [1906].

ENGLAND AND WALES. Sovereign (Elizabeth I) (1589), By the Queen. A proclamation against certaine seditious and schismatical books and libels, \&c., London: by the deputies of Christopher Baker.

ENGLAND AND WALES. Sovereign (Elizabeth I) (1602), By the Queene a proclamation for proceeding against Iesuites and secular priests, their receiuers, relieuers, and maintainers, London: Robert Barker.

ENGLAND AND WALES. Sovereign (James I) (1603a), By the King. A Proclamation for the authorizing and vniformitie of the Booke of Common Prayer to be vsed throughout the realme, London: Robert Parker.

ENGLAND AND WALES. Sovereign (James I) (1603b), By the King although it cannot be without griefe to vs to publish, that in this our Kingdome we should finde any subject so contrary to all the rest of our louing people who ..., London: Robert Barker. 
FÉRAUD, Jean-François (1786), Dictionaire critique, de la langue française, Marseille: Jean Mossy.

FINNEY, C. G. (1835), Lectures on Revivals of Religion, second edition, New York: Leavitt, Lord \& Co.

FORMEY, Jean Henri Samuel (1756), Pensées raisonnables opposées aux Pensées Philosophiques. Avec un essai de critique sur le livre intitulé Les moeurs et la Lettre de Gervaise Holmes à l'auteur de celle sur les aveugles, Guttingue \& Leide: Elie Luzac fils.

JAVARY, Louis-Auguste (1851), De l'idée de progrès, Paris: Librairie philosophique de Ladrange.

JOURDAN, Athanase Jean Léger, Alphonse-Honoré Taillandier Decrusy and François-André Isambert (1789), Recueil général des anciennes lois françaises, depuis l'an 420 jusqu'à la révolution de 1789, contenant la notice des principaux monumens des Mérovingiens, des Carlovingiens et des Capétiens, et le texte des ordonnances, édits, déclarations, lettres-patentes, réglemens, arrêts du Conseil, etc., de la troisième race, qui ne sont pas abrogés, ou qui peuvent servir, soit à l'interprétation, soit à l'h凶istoire du droit public et privé, avec notes de concordance, table chronologique et table générale analytique et alphabétique des matières, Paris: Belin-en-Prieur et Verdière.

LACHAT, François (1864), Oeuvres complètes de Bossuet, publiées d'après les imprimés et les manuscrits originaux, purgées des interpolations et rendues à leur intégrité, tome 24, Paris: Louis Vives.

LALLY-TOLLENDAL, Gérard-Trophisme (1789), Discours de M. de Lally-Tollendal, sur le projet d'adresse au roi, 15 juin 1789, in: Politicon ou choix des meilleurs discours; sur tous les sujets de politique, traités dans la première assemblée nationale de France, ed. L. S. de Balestrier-Canilhac, tome premier, Paris: Laurent \& Lacloye: 157-65.

LAURENT, François (1866), Études sur l'histoire de l'humanité - La philosophie du XVIIIe siècle et le christianisme, Paris: Librairie internationale.

LAURENT, François (1879), Études sur l'histoire de l'humanité - La réforme, Paris: C. Marpon et E. Flammarion.

LOUIS XVI (1775), Lettres-patentes du Roi, sur une Convention conclue entre le Roi, l'Empereur \& l'Impératrice Reine de Hongrie \& de Bohème, concernant les Bénéfices réguliers dépendans des Abbayes situées en France \& dans les Pays-Bas Autrichiens, in Recueil des édits, déclarations, lettres-patentes, \&oc. enregistrées au Parlement de Flandres, des arrêts du conseil d'État, particuliers à son ressort, ensemble des arrêts de réglemens rendus par cette cour, depuis son érection en Conseil Souverain à Tournay, Volume 7, Douai \{1787]: Derbaix: 776-80.

MERCIER, Louis-Sébastien (1792), Fragments de politique et d'histoire, volume 1, Paris: Buisson.

MÉRILHOU, Joseph (1825), Euvres de Mirabeau, précédées d'une notice sur sa vie et ses ouvrages: discours et opinions, tome 1, Paris: Brissot-Thivars.

NASH, Samuel John (1800), An Address to the Board of Agriculture on the Subject of Enclosure and Tithes.

NAVARRE (Kingdom). Sovereign (Henri III) (1586), Three letters written by the King of Nauarre first Prince of the bloud and chiefe peere of France to the states of the cleargie, noblitie and third estate of France. More: a letter from the sayd King to the Gouernors and communaltie of the towne of Paris. All faithfully translated out of the 
French., At London: Printed [by George Robinson] for Edward Aggas.

NAVARRE (Kingdom). Sovereign (Henri III) (1589), A letter written by the king of Nauarr, to the three estates of Fraunce containing a most liuely description of the discommodities and dangers of ciuill warre: and a very forcible perswasion to obedience, vnitie, and peace. Together with a breefe declaration vpon the matters happened in Fraunce sithence the 23. day of December. 1588. Translated out of French, by G. R., At London: Printed by Thomas Purfoote, and are to be sould at his shop ouer against $S$. Sepulchres Church without Newgate.

NECKER, Jacques (1792), Du pouvoir exécutif dans les grands États, tome second, Paris.

OPUSCULES de M. Bossuet, évêque de Meaux (1751), tome 5, Paris: Le Mercier; Dessaint \& Saillant; Jean-Th. Herissant; Durand; Le Prieur.

PATTERSON, John (1850), Innovation Entitled to a Full and Candid Hearing, New York: Fowlers and Wells.

PIGOTT, Charles (1792), The Jockey Club or a Sketch of the Manners of the Age, London: M. D. Symons, Paternoster-Row.

PRUDHOMME, Jean-Marie (1789), Résumé général, ou Extraits des Cahier de Pouvoirs, Instructions, Demandes et Doléances, remis par les divers Baillages, Sénéchaussées et pays d'Etats du Royaume, à leurs Députés à l'Assemblée des Etats-Généraux, ouverts à Versailles, le 4 mai 1789, Société des gens de lettres, tome premier, Paris: L'Editeur.

ROBINSON, Robert (1782), On Innovation, in Arcana: The Principles of the Petitioners in Eight Letters to a Friend, London: 55-63.

ROUILLÉ d'Orfeuil, Gaspard-Louis (1773), Innovation, in L'alambic des Loix, ou observations de l'ami des François. sur l'homme et les loix, Morocco: Hispaan: 76-77.

ROUSSEAU, Jean-Jacques (1764), Lettres écrites de la montagne, seconde partie, Amsterdam: Marc Michel.

SIEYĖS, Emmanuel-Joseph (1789), Qu'est-ce que le Tiers-État, Paris.

SWIFT, Jonathan (1726), Travels into several remote nations of the world. In four parts. By Lemuel Gulliver, First a Surgeon, and then a Captain of several ships, Dublin: J. Hyde.

TARDE, Gabriel (1890), Les lois de l'imitation. Paris: Seuil [2001].

TARGET, G. J. B. (1789), L'esprit des cahiers, présentés aux États-Généraux de l'an 1789, augmenté de vues nouvelles, ou projet complet de la régénération du royaume de France. Le tout en bref, tome premier, Paris.

TINSEAU-D’Amondans, Charles Marie Thérèse Léon (1792), Parallèle des deux déclarations du Roi, faites le 23 juin 1789 et des principales innovations proposées de nos jours, avec la véritable constitution françoise (originally published end 1791), Paris.

\section{References}

ARENDT, Hannah (1963), On Revolution, New York: Penguin Books.

BAKER, Keith M. (1990), Inventing the French Revolution, Cambridge: Cambridge University Press.

BAKER, Keith M. (1988), "Revolution", in C. Lucas (ed.), The Political Culture of the French Revolution, Oxford: Pergamon Press: 41-62. 
BAECQUE, Antoine (1988), L’homme nouveau est arrivé: la "régénération" du Français en 1789, Dix-Huitième Siècle, 20:193-208.

BALL, Terrence, and John G. A. Pocock (1988) (eds.), Conceptual Change and the Constitution, Lawrence (Kansas): University Press of Kansas.

BARNY, Roger (1978), Les mots et les choses chez les hommes de la révolution française, La pensée, 202: 96-115.

BURNETT, Joe R., and John R. Palmer (1967), Radical, Liberal, Conservative, Reactionary: Making Them Distinctions Which Distinguish, Studies in Philosophy and Education, 5 (2): 225-44.

CRIMMINS, James (1998), Political Economy and Projectors: Bentham's Defence of Usury, Conference paper, St. Petersburg Center for the History of Ideas. Available at http://ideashistory.org.ru/almanacs/alm09/07.

EDELSTEIN, Ludwig (1967), The Idea of Progress in Classical Antiquity, Baltimore (Maryland): Johns Hopkins University Press.

GODIN, B. (Forthcoming-A), Innovation Contested: The Idea of Innovation Over the Centuries, London: Routledge.

GODIN, B. (Forthcoming-B), Re-Imagining Innovation in the Nineteenth Century: A Study in the Rehabilitation of a Concept, Contributions to the History of Concepts.

GODIN, Benoît (2012-13), The Politics of Innovation: Innovation and Republicanism in Seventeenth Century England, Redescription, 16

GODIN, Benoît (2010), "Meddle Not With Them That Are Given to Change": Innovation as Evil, Project on the Intellectual History of Innovation, paper no. 6, Montreal: INRS.

GOULEMOT, Jean Marie (1968), Emploi du mot "révolution" dans les traductions françaises du XVIIIe siècle des discours de Nicolas Machiavel, Cahiers de lexicographie, $13:$ 75-83.

KOSELLECK, Reinhart (1968), Modernity and the Planes of Historicity, in R. Koselleck, Futures Past: On the Semantics of Historical Time, New York: Columbia University Press, 2004: 9-25.

KOSELLECK, Reinhart (1969), Historical Criteria of the Modern Concept of Revolution, in R. Koselleck, Futures Past: On the Semantics of Historical Time, New York: Columbia University Press, 2004: 43-71.

KOSELLECK, Reinhart (1972), Begriffsgeschichte and Social History, in R. Koselleck, Futures Past: On the Semantics of Historical Time, New York: Columbia University Press, 2004: 75-92.

KOSELLECK, Reinhart (1977), Neuzeit: Remarks on the Semantics of Modern Concepts of Movement, in R. Koselleck, Futures Past: On the Semantics of Historical Time, New York: Columbia University Press, 2004: 222-54.

KOSELLECK, Reinhart (2002a), Concepts of Historical Time and Social History, in R. Koselleck, The Practice of Conceptual History: Timing History, Spacing Concepts, Stanford: Stanford University Press: 115-30.

KOSELLECK, Reinhart (2002b), The Practice of Conceptual History: Timing History, Spacing Concepts: Stanford: Stanford University Press.

LADNER, Gerhart B. (1959), The Idea of Reform, Cambridge (Mass.): Harvard University Press. 
LÜSEBRINK, Hans-Jurgen and Rolf Reichardt (1988), Révolution à la fin du 18e siècle, Mots, 16: 36-69.

MAUZI, Robert (1979), L’idée de bonheur dans la littérature française au XVIIIe siècle, Paris: Albin Michel.

NISBET, Robert A. (1969), Social Change and History, London: Oxford University Press.

NISBET, Robert A. (1980), History of the Idea of Progress, New York: Basic Books.

OZOUF, Mona (1989), Revolution, in F. Furet and M. Ozouf (eds.), A Critical Dictionary of the French Revolution, Cambridge (Mass.): Harvard University Press [1989]: 806-17.

REICHARDT, Rolf (1997), Révolution, in M. Delon (ed.), Dictionnaire européen des lumières, Paris: Presses universitaires de France.

RICKEN, Ulrich (1982), Réflexions du XVIIIe siècle sur "l'abus des mots", Mots, Mars: 29-45.

RICHTER, Melvin (1995), The History of Political and Social Concepts: A Critical Introduction, Oxford: Oxford University Press.

RITCHIE, Daniel E. (ed.) (1991), Burke, Edmund. Further Reflections on the Revolution in France, Liberty Fund, Indianapolis (Indiana).

SEWELL, William H. (2005), Logics of History: Social Theory and Social Transformations, Chicago: University of Chicago Press.

SKINNER, Quentin (2002), Moral Ambiguity and the Renaissance Art of Eloquence, in Q. Skinner Visions of Politics, vol. 2: Renaissance Virtues, Cambridge: Cambridge University Press: 264-85.

SLAUGHTER, Mary M. (1982), Universal Languages and Scientific Taxonomy in Seventeenth Century, Cambridge: Cambridge University Press.

STEDMAN Jones, Gareth (2010), Religion and the Origin of Socialism, in I. Katznelson and G. Stedman Jones (eds.), Religion and the Political Imagination, Cambridge: Cambridge University Press: 171-89.

\section{Annex}

John Patterson's Characteristics of Innovators and Anti-Innovators

\section{The Anti-Innovator.}

1. Those who cannot appreciate the evidence. These men are "innocent in their opposition ... [and] in no respect culpable".

2. Those who will not make themselves acquainted with the new doctrines".

a. Those who are too dilatory to examine. "Light is of no use to them"; "new things are repulsive, and the "good old way" the best".

b. Those who are merged in worldly cares. These are "the slaves of ambition, avarice, or necessity"; they are "the friends of nothing new, till it becomes 
popular".

c. Those who are actuated by selfish interest, i.e. those "educated in a certain school", the partisan, the orthodox.

d. Those whom envy actuates. He envies success or talents.

e. Those who want to lead in every thing.

f. Those who are naturally of an incredulous and wary disposition.

g. Many oppose reform just because some reputed great man does, or because it is fashionable to do so.

h. Such as have been deceived once, or have discovered deceptions on other occasions.

i. Those who fear to investigate lest they will be obliged to receive.

$\mathrm{j}$. Those who inherit all true doctrines, i.e. biases in early life (education). These men "have furnished the world with nearly all the persecuting sectaries. They had recourse to the more effectual method of the sword, fire and faggot, the scaffold, the rack, the dungeon, and all the instruments of torture".

3. Those who appreciate the claims of the new doctrine, but do not espouse it (conservatives).

a. Those subject to temporal necessities. "They would be abandoned by their patrons, lose their salaries, and, perhaps, unable to find other employment, become beggared".

b. Those who are the slaves of habit.

c. Those who are bound to hoary error by the ties of friendship.

d. The votaries of false honor ("fear of losing the reputation they have won").

e. Those who have predominant pride of opinion.

f. Timid spirits. They lose ease, they choose peace.

g. Those who apprehend danger from reformatory efforts.

h. Those who doubt the expediency of engaging in the work of reform themselves.

\section{The Innovator.}

1. Receives no doctrine or opinion upon the mere authority of others.

2. Condemns nothing unheard.

3. For the purpose of being able to deliberate with candour and impartiality, he studies himself (mental discipline: he studies his judgments and the prejudices of his education).

4. Is willing to be convinced. "He rejects nothing new because it is new ... and clings to nothing old because it is old". He is open-minded.

5. Adopts his views regardless of praise or censure. "He chooses the right rather than the popular". 
6. Fearlessly proclaims his honest convictions.

7. The true reformer rather courts than shuns the censure of errorists. He is independent; he examines carefully; he stoops to artifice.

8. Adapts himself to progress ("an essential characteristic").

9. Is not afraid of heresy. He is liberal.

10. Has no vulgar fears about stability of mind. He is changeable but yields to no influence. He investigates. His basis is evidence. His changes are advances. 11. Never condescends to vulgar abuse.

12. In matters of mere opinion he usurps no undue authority. He accepts differences of opinion and "wishes the kind of assistance of those who are better informed".

13. Extends the hand of fellowship to all mankind. He tries to alter the sufferings of man.

14. In faith, as in other things, he is progressive, "regardless of consequences". 